\title{
Penerapan Scientific Approach Dalam Group Investigation Untuk Meningkatkan Keterampilan Berpikir Kritis Siswa Sekolah Dasar
}

\author{
Titin Sunaryati*, Nur Luthfi Rizqa Herianingtyas
}

\author{
${ }^{1}$ Program Studi Pendidikan Guru Sekolah Dasar, Universitas Pelita Bangsa, Bekasi, Jawa Barat \\ Indonesia \\ ${ }^{2}$ Program Studi Pendidikan Guru Madrasah Ibtidaiyah, Universitas Islam Negeri Syarif Hidayatullah \\ Jakarta, Indonesia \\ E-mail: titinsunaryati@pelitabangsa.ac.id
}

\begin{abstract}
Abstrak
Tujuan penelitian ini yaitu untuk meningkatkan keterampilan berpikir kritis ssiwa melalui penerapan scientific approach dalam group investigation. Penelitian ini merupakan penelitian tindakna kelas menggunakan desain model Kemmis \& Taggart. Subjek penelitian adalah siswa kelas IV berjumlah 35 siswa. Teknik pengumpulan data yang digunakan adalah observasi, tes, dan dokumentasi. Data yang terkumpul dianalisis dengan teknik deskriptif komparatif. Pembelajaran dilaksanakan dengan langkah-langkah: (1) Goals, (2) Motivation, (3) Planning Activities; (4) Materials; (5) Group Activities; (6) Closure; (7) Appraisal and Feedback; and (8) Reflection. Hasil penelitian menunjukan bahwa penerapan scientific approach dalam group investigation dapat meningkatkan keterampilan berpikir kritis siswa dalam pembelajaran IPA. Diketahui Presentase keterampilan berpikir kritis siswa mengalami peningkatan pada setiap pertemuannya. Pada siklus I skor rata - rata 23,4 dengan presentase $68,57 \%$ berada dalam kategori Cukup. Kemudian mengalami peningkatan pada siklus II yaitu mencapai 29,5 dengan presentase ketercapaian 85,71\% dalam kategori Amat Baik. Pada siklus III terus mengalami peningkatan menjadi 32,5 atau 91,42\% dalam kategori Amat Baik. Dari hasil tes tersebut diketahui bahwa keterampilan berpikir kritis siswa mengalami peningkatan dan telah mencapai target yang diinginkan yaitu $\geq 80 \%$.
\end{abstract}

Kata Kunci: critical thinking skills, group investigation, scientific approach

\begin{abstract}
The aim of this study was to improve students' critical thinking skills through the application of the scientific approach in group investigation. This research is a classroom action research using the Kemmis \& Taggart model design. The research subjects were grade IV students totaling 35 students. The data collection techniques used were observation, tests, and documentation. The collected data were analyzed using comparative descriptive techniques. Learning is carried out in steps:(1) Goals, (2) Motivation, (3) Planning Activities; (4) Materials; (5) Group Activities; (6) Closure; (7) Appraisal and Feedback; and (8) Reflection. The results showed that the application of the scientific approach in group investigation could improve students' critical thinking skills in science learning. It is known that the percentage of students' critical thinking skills has increased at each meeting. In the first cycle the average score was 23.4 with a percentage of $68.57 \%$ in the Enough category. Then it increased in cycle II, reaching 29.5 with a percentage of achievement of $85.71 \%$ in the Very Good category. In the third cycle, it continued to increase to 32.5 or $91.42 \%$ in the Very Good category.
\end{abstract}

Keywords: critical thinking skills, group investigation, scientific approach 


\section{PENDAHULUAN}

Pendidikan di Indonesia dirumuskan menjadi empat jenjang utama yaitu pendidikan anak usia dini, dasar, menengah, dan tinggi. Pendidikan dasar atau yang biasa disebut dengan istilah Pendidikan di Sekolah Dasar (SD) merupakan jenjang pendidikan yang harus ditempuh anak Indonesia sebelum menuju jenjang sekolah menengah pertama. Sekolah Dasar merupakan sistem penyelenggara pendidikan nasional yang bertugas meletakan dasar-dasar pengetahuan, keterampilan, dan nilai-nilai, sehingga kedudukannya sangat penting sebagai batu loncatan proses diawalinya seseorang mendapatkan konsep dasar pengetahuan yang benar, keterampilan hidup yang beragam, serta penanaman nilainilai karakter yang ketiganya harus memiliki relevansi dengan kehidupan pada masa itu serta dapat digunakan pada masa mendatang.

Namun pada kenyataannya berdasarkan kenyataan di lapangan, Kemendikbud (2016) menyampaikan bahwa kemampuan dalam pemahaman informasi yang kompleks, teoretis, analitis, pemakaian alat, prosedur pemecahan masalah, serta proses investigasi atau penyelidikan pada peserta didik Indonesia masih rendah, sehingga kualitas pendidikan di Indonesia terutama di sekolah dasar belum mengoptimalkan kegiatan yang membangun kemampuan berpikir tingkat tinggi seperti pemecahan masalah, berpikir kreatif, metakognisi, dan berpikir kritis.

Studi internasional juga melaporkan beberapa hasil monitoring sebagai berikut: (1) UNESCO mencatat bahwa The Education for All Development Index (EDI) Indonesia pada tahun 2014 berada pada peringkat 57 dari 115 negara di dunia."; (2) UNESCO, BBC dan Financial Times juga menuliskan bahwa hasil penilaian dari Organisasi Kerjasama Ekonomi Pembangunan atau Organitation for Economic Co-Operation and Development (OECD) menyatakan bahwa kualitas pendidikan Indonesia jika dibandingkan secara internasional, berada di peringkat delapan dari bawah, yaitu 69 dari 76 negara.

Berdasarkan hasil observasi peneliti di SDN Ploso I Kelas IV diketahui bahwa kemampuan berpikir kritis siswa masih lemah, terbukti dari hasil tes berpikir kritis dalam pembelajaran IPA hanya mencapai $68 \%$ dari standar yang ditargetkan yaitu $80 \%$.

Berpikir kritis merupakan keterampilan berpikir tingkat tinggi dalam kehidupan manusia. Beberapa alasan pentingnya menciptakan pembelajaran bernuansa kritis dan penuh pengalaman menurut Özden (2008) adalah bahwa saat ini karena peserta didik akan mengalami kebermaknaan belajar ketika mereka mengalami dan berpikir secara kritis atas kejadian yang mereka alami tersebut artinya tentang bagaimana proses belajar itu terjadi, sehingga dalam menyongsong abad 21 ini dunia pendidikan perlu diwarnai dengan kualitas tentang bagaimana proses belajar yang tepat, salah satunya diawali dengan adanya perubahan yang mendasar atas kedudukan seorang guru di kelas yaitu guru harus berperan sebagai seorang fasilitator yang mampu memfasilitasi siswa untuk memiliki pengalaman langsung serta berperan secara aktif dan kritis dalam pembelajaran. 
Demir (2010) mencontohkan beberapa negara yang mengorientasikan keterampilan berpikir kritis di kelas, yaitu di China dan Turki. Kedua negara tersebut, pembelajaran berbasis pemecahan masalah telah diterapkan sejak di kelas 4 sekolah dasar untuk mengasah kemampuan siswa dalam memberikan solusi atas suatu masalah.

Berpikir kritis merupakan bagian dari proses berpikir yang memiliki kedudukan penting dalam taksonomi kemampuan kognitif. Kemunculannya diharapkan hadir dalam setiap pemecahan masalah, agar permasalahan dapat diselesaikan dengan prosedur dan strategi yang tepat serta telah melalui beberapa pertimbangan. Brookfield mempresentasikan berpikir kritis sebagai sebuah kebiasaan yang dapat memastikan asumsinya merupakan asumsi yang akurat, sehingga tindakan yang dilakukan akan membuahkan hasil yang valid dan tepat. Dengan demikian, tujuan dari berpikir kritis adalah untuk menghasilkan keputusan atas dasar yang relevan.

Pada prinsipnya siswa yang memiliki keterampilan berpikir kritis akan melakukan banyak pertimbangan sebelum melangkah dan membuat keputusan, langkah yang dilakukannya penuh dengan ketelitian dan kehati-hatian. Moon (2008) memiliki perspektif bahwa dengan adanya berpikir kritis akan terwujud ide-ide yang kompleks dimana seseorang dapat membuat keputusan atas bukti yang rasional. Seseorang yang memiliki keterampilan berpikir kritis dapat menyaring mana bukti yang relevan dan tidak relevan, memutuskan apa yang dapat digunakan dan tidak digunakan. Bahkan akan melakukan berlang-ulang pengujian untuk benar-benar memperoleh hasil dan keputusan yang tepat, ajeg, dan akurat.

Berpikir kritis sama artinya dengan berpikir reflektif lebih mendalam, dimulai dari memahami titik permasalahan, mencari berbagai sumber dan bukti relevan, melakukan analisis atau pengujian, hingga mencetuskan suatu keputusan yang tepat untuk memecahkan masalah tersebut. Trilling \& Fadel (2009) memandang berpikir kritis sebagai suatu kegiatan menganalisis, menafsirkan, mengevaluasi, meringkas, dan mensintesis semua informasi dan menerapkan hasilnya untuk memecahkan masalah, ide, dan menghindari prasangka untuk memecahkan masalah dengan tepat. Di dalam konteks yang saling beriringan, Judge (2009) menggambarkan berpikir kritis sebagai suatu pernyataan dan pertanyaan yang mendasar, beralaskan bukti relevan dan akurat. Kalimat tersebut merujuk pada suatu pemaknaan bahwa orang yang berpikir kritis akan selalu mencari bukti yang kuat untuk mengungkapkan gagasannya dan selalu berpikir mendalam dalam menuangkan pertanyaannya, sehingga proses pemecahan masalah yang dilakukan didasari pada bukti yang akurat, berawal dari bukti dan informasi itulah akan mucul ide dan atau gagasan yang tepat dan relevan.

Sudut pandang tentang berpikir kritis ini kemudian mendapatkan tanggapan dari Kemendikbud (2016) bahwa berpikir kritis sama saja dengan "out of the box" yaitu suatu proses berpikir yang berbeda dari yang biasanya, proses berpikir yang selalu 
mengutamakan bukti dan informasi, serta proses berpiir yang akan selalu berusaha mencari tahu kebenaran secara mendalam. Kajian ini dapat diartikan pula sebagai suatu jalan untuk berusaha memandang suatu objek dari segi yang berbeda dan keakuratan informasi merupakan bekal dalam proses berpikirnya.

Kaitannya dengan penelitian ini, keterampilan berpikir kritis tidak dapat dilihat dengan kasat mata, namun dapat diketahui dari bagaimana sudut pandang siswa dalam memecahkan masalah dan membuat keputusan atas permasalahan tersebut. Sebagai suatu bagian dari kemampuan berpikir, terdapat unsur-unsur yang dapat mencirikan bahwa seseorang itu memiliki keterampilan berpikir kritis. Keterampilan berpikir kritis yang dimiliki pada setiap tahapan perkembangan manusia berbeda-beda. Anak-anak dengan orang dewasa tentu memiliki taraf berpikir kritis yahng tidak sama. Sebab itu, dalam ruang penelitian ini akan diidentifikasi kapasitas indikator keterampilan berpikir kritis siswa kelas IV sekolah dasar.

Ennis (2000) menamai komposisi keterampilan berpikir kritis sebagai FRISCO yang (1) Focus (fokus) merupakan kegiatan memusatkan perhatian, yaitu fokus pada inti permasalahan sebelum memutuskan strategi untuk menyelesaikannya; (2) Reason (alasan) merupakan suatu argumen dasar dalam membuat suatu kesimpulan, argument tersebut didapatkan dari rangkaian teori yang diformulasikan sebagai bahan dari pertimbangan; (3) Inference (kesimpulan) merupakan kemampuan untuk membuat kesimpulan atas alasan yang telah dikemukakan. Situation (situasi) sebagai kemampuan dalam menjawab soal sesuai dengan konteks permasalahan; (4) Clarity (kejelasan) merupakan kejelasan dari bahasa yang digunakan agar bersifat komunikatif yaitu mudah dimengerti; (5) Overview (menyeluruh) yaitu melihat sesuatu secara keseluruhan apakah terdapat koherensi dan relevansi antara permasalahan dan keputusan yang telah diambil.

Unsur dasar berpikir yang digambarkan melalui FRISCO, memberikan pemahaman bahwa proses berpikir yang bersifat kritis, tidak hanya dipandang dari satu sisi saja, namun melalui beragam proses pertimbangan yang dipikirkan untuk menghasilkan kesimpulan yang relevan dengan konteks permasalahan

Sejalan dengan itu, Ennis, Leicester \&Taylor (2010) menyusun dimensi berpikir kritis meliputi: (1) Asking questions (membuat pertanyaan); (2) Point of view (sudut pandang); (3) Being rational (rasional), (4) Tools of critical thinking: fiding out (alat berpikir kritis: mencari tahu), dan (5) Analysis (menganalisis).

Di arah yang bersamaan, kemunculan berpikir kritis tersebut dapat dikemas dengan adanya corak pembelajaran yang mengarah pada internalisasi 5 dimensi keterampilan berpikir kritis. Salah satunya yaitu pembelajaran berbasis scientific approach. Scientific approach yang biasa dikenal sebagai pendekatan saintifik menurut Danim (2014) merupakan perwujudan dari dimensi pengamatan, penalaran, penemuan, pengabsahan, dan penjelasan tentang suatu kebenaran yang dipandu dengan nilai, prinsip, 
serta kriteria ilmiah. Komponen pendekatan saintifik yang dimaksud yaitu mengamati, menanya, menalar, mencoba, dan mengkomunikasikan.

Pakar pendidikan dalam beberapa tahun terakhir ini telah melakukan beberapa penelitian dengan mengangkat tema pendekatan saintifik (scientific approach). Seperti halnya Odom yang pada tahun 2005 melaporkan bahwa di Amerika Serikat juga diterapkan scientific approach, tujuan diterapkannya scientific approach di Amerika Serikat adalah untuk menghadirkan ruang belajar siswa yang identik dengan ruang kerja, artinya substansi yang dipelajari oleh siswa dalam dunia pendidikan sama dengan apa yang akan mereka aplikasikan dalam dunia kerja. Hasil temuan ini menimbang pentingnya relevansi antara outcome dengan intput yang diberikan. Paradigma ini merujuk pada suatu kesimpulan bahwa ruang belajar siswa saat ini merupakan kawah candra dimuka yang akan membekali siswa life skill dan work skill sebagaimana nantinya ketika mereka terjun dalam dunia yang sesungguhnya.

Di tahun 2013 juga terdapat penelitian yang telah melaporkan bahwa scientific approach dapat meningkatkan pemahaman konsep pada materi sifat-sifat cahaya pada siswa kelas V. Pemahaman konsep juga merupakan bagian dari ranah kemampuan berpikir yang menduduki tingkat $\mathrm{C} 1$. Kondisi potensial tersebut dapat menjadi gambaran bahwa scientific approach dapat meningatkan ranah kognitif seseorang, oleh karena itu dalam penelitian ini akan difokuskan pada bagaimana penerapan scientific approach terhadap peningkatan keterampilan berpikir kritis yang berada pada ranah kognitif C5. Dengan pertimbangan benang merahnya bahwa scientific approach yang meliputi kegiatan mengamati, menanya, menalar, mencoba, dan mengkomunikasikan dapat menjadi sarana mewujudkan siswa yang berpikir kritis, yaitu siswa yang memiliki keterampilan untuk menemukan suatu ide-ide yang kompleks, membuat keputusan atas bukti yang rasional, menyaring bukti yang relevan, serta melakukan berlang-ulang pengujian untuk benar-benar memperoleh hasil dan keputusan yang tepat, ajeg, dan akurat.

Selanjutnya, roda perjalanan Kurikulum 2013 juga diiringi dengan model-model pembelajaran yang diekspetasikan dapat membawa pendidikan ke arah terwujudnya pembelajaran kritis, diantaranya: problem solving, problem based learning, project based learning, inquiri, group investigation dan discovery learning. Dari beberapa model pembelajaran yang disarankan oleh pemerintah tersebut, model pembelajaran group investigation merupakan model yang pada saat ini banyak mendapat sorotan publik terutama para pakar pendidikan.

Dengan menyatukan siswa dalam suatu kelompok-kelompok, siswa akan menunjukkan kemampuan dan keterampilan mereka, berbagi informasi, serta mendengar atau membahas sumbangan informasi dari siswa lainnya. Dengan cara seperti ini akan muncul "keseragaman" di dalam heterogenitas siswa. Group investigation merupakan salah satu dari bermacam-macam pembelajaran yang bersifat kolaboratif. Kemendikbud (2014) menjelaskan 
bahwa melalui Group Investigation semua anggota kelompok dituntut untuk merencanakan suatu penelitian beserta perencanaan pemecahan masalah yang dihadapi. Kelompok menentukan apa saja yang akan dikerjakan dan siapa saja yang akan melaksanakannya berikut bagaimana perencanaan penyajiannya di depan forum kelas.

Terdapat tiga konsep utama terkait dengan Group Investigation (GI) yaitu: penelitian, pengetahuan, dan dinamika kelompok (Winaputra, 2001). Penelitian dalam hal ini adalah proses dinamika siswa memberikan respon terhadap masalah dan memecahkan masalahh tersebut. Pengetahuan adalah pengalaman belajar yang diperoleh siswa baik secara langsung maupun tidak langsung. Sedangkan dinamika kelompok menunjukan anggota kelompok yang saling berinteraksi bertukar informasi dan memberikan argumentasi.

Siswa dilibatkan dalam perencanaan dan pemilihan sub topik sebelum diadakan suatu penyelidikan. Sharan \& Sharan (1989) menegaskan bahwa di dalam Group Investigation siswa turut mengambil bagian untuk merencanakan apa yang akan mereka pelajari dan bagaimana melakukannya. Mereka membentuk grup yang saling bekerjasama untuk melakukan penyelidikan suatu sub topik tertentu. Diantara beberapa kelompok melakukan penyelidikan dengan sub topik yang berbeda-beda. Setelah melaksanakan penyelidikan, masing-masing kelompok menyampaikannya kepada ke kelompok lain hasil penyelidikannya tersebut.
Kelebihan model pembelajaran GI dibandingkan model pembelajaran kooperatif lainnya adalah memungkinkan siswa menggunakan keterampilan inkuiri yang mampu mempersiapkan masa depan siswa, lebih percaya pada kemampuan sendiri untuk berpikir, mencari informasi dari sumber lain, dan dapat belajar dari siswa lain (Sharan 1990). Dengan demikian, model pembelajaran GI dapat mendorong siswa belajar lebih aktif dan lebih bermakna. Artinya, siswa dituntut berpikir suatu persoalan dan mencari cara penyelesaiannya sendiri. Oleh karena itu, siswa lebih terlatih untuk menggunakan keterampilan pengetahuannya sehingga pengetahuan dan pengalaman belajar siswa dapat tertanam untuk jangka waktu yang lama.

Group Investigation merupakan salah satu bentuk model pembelajaran kooperatif yang fokus pada partisipasi dan aktivitas siswa untuk mencari sendiri materi (informasi) pelajaran yang akan dipelajari melalui bahanbahan yang tersedia, misalnya dari buku pelajaran atau siswa dapat mencari sendiri melalui internet. Siswa dilibatkan sejak perencanaan, baik dalam menentukan sub topik dan mempelajari sesuatu melalui penyelidikan.

Para guru yang menggunakan metode Group Inverstigation umumnya membagi kelas menjadi beberapa kelompok yang beranggotakan 5 sampai 6 siswa dengan karakteristik yang heterogen, (Trianto, 2007). Pembagian kelompok dapat juga didasarkan atas kesamaan minat terhadap suatu sub topik tertentu. Selanjutnya siswa memilih sub topik untuk diselidiki, melakukan penyelidikan yang mendalam atas sub topik yang telah dipilih, 
kemudian menyiapkan, melakukan penyelidikan, kemudian mempresentasikan laporannya di depan kelas. Howe \& Linda (1993) menjelaskan langkah-langkah unit perencanaan Group Inverstigation yaitu: (1) Goals, (2) Motivation, (3) Planning Activities; (4) Materials; (5) Group Activities; (6) Closure; (7) Appraisal and Feedback; and (8) Reflection.

Dari berbagai penelitian dan teori yang disebutkan di atas, perlu diadakan penelitian yang dapat mengungkap penerapan scientific approach dalam group investigation meningkatkan keterampilan berpikir kritis siswa kelas IV sekolah dasar pada pembelajaran IPA. Oleh karena itu, penelitian ini diarahkan untuk: (1) Mendeskripsikan langkah-langkah penerapan scientific approach melalui group investigation; (2) Meningkatkan keterampilan berpikir kritis siswa; (3) Meningkatkan hasil belajar siswa dalam pembelajaran IPA.

\section{METODE PENELITIAN}

Penelitian ini dilaksanakan di kelas IV SD Negeri Ploso I, Kecamatan Pacitan, Kabupaten Pacitan, Subjek penelitian adalah siswa kelas IV SDN Ploso I tahun ajaran 2016/2017 yang berjumlah 35 siswa terdiri dari 13 siswa laki-laki dan 22 siswa perempuan. Alat pengumpulan data dalam penelitian ini yaitu instrumen tes berupa soal evaluasi, dan instrumen non tes berupa lembar observasi, dan dokumentasi. Pelaksana tindakan ialah guru kelas IV sekolah dasar. Observer dalam penelitian ini yaitu peneliti, guru kelas III, dan guru kelas V.
Data dalam penelitian ini terdiri dari data kuantitatif yang berupa hasil tes kemampuan berpikir kritis siswa. Data kuantitatif tersebut dianalisis dengan teknik statistik deskriptif komparatif. Sedangkan data kualitatif dalam penelitian ini berupa hasil observasi penerapan scientific approach dalam group investigation. Data kualitatif dalam penelitian ini dianalisis sesuai dengan model analisis data menurut Miles dan Huberman (2014) yang meliputi: (1) reduksi data; (2) penyajian data; dan (3) penarikan kesimpulan.

Penelitian ini menggunakan teknik triangulasi sumber yang berasal dari siswa, guru, dan observer. Teknik pengumpulan data adalah dengan tes, observasi, dan dokumentasi.

Teknik pengumpulan data adalah dengan tes, observasi, dan dokumentasi. Indikator kinerja penerapan scientific approach dalam group investigation adalah $\geq 80 \%$. Kemampuan berpikir kritis siswa sebesar $\geq 80 \%$.

Penelitian ini merupakan jenis Penelitian Tindakan Kelas (PTK) yang bersifat kolaboratif. Prosedur penelitian ini menggunakan siklus kegiatan yang dilaksanakan selama tiga siklus, masing-masing siklus terdiri dari dua pertemuan. Setiap pertemuan terdiri dari empat tahapan yaitu: (1) perencanaan; (2) pelaksanaan; (3) pengamatan, dan (4) refleksi.

\section{HASIL PENELITIAN}

Implementasi scientific approach dalam model pembelajaran group investigation dilaksanakan selama 3 siklus yaitu siklus I, II, dan III, masing-masing siklus terdiri dari 2 pertemuan. Data hasil observasi 
keterlaksanaan implementasi scientific approach dalam group investigation disajikan dalam Tabel 1.

Berdasarkan Tabel 1, dapat diketahui hasil rata-rata observasi guru pada siklus I sebesar 3,35 atau $83,75 \%$ termasuk dalam kategori baik dan pada siklus II mengalami peningkatan menjadi 3,55 atau $88,75 \%$ terkategori amat baik, selanjutnya pada siklus III kembali meningkat menjadi 3,70 atau 92,50\% termasuk dalam kategori amat baik, dari hasil tersebut diketahui pelaksanaannya oleh guru telah mencapai hasil yang amat baik dan mencapai indikator pencapaian yang diharapkan yaitu $\geq 80 \%$. Dari tabel di atas juga diketahui hasil observasi penerapan scientific approach dalam group investigation dari sisi siswa juga mengalami peningkatan setiap siklusnya. Pada siklus I 3,25 atau 81,25 \%, pada siklus II sebesar 3,45 atau $86,25 \%$ dan pada siklus III sebesar 3,65 atau 91,25\%, sehingga diketahui sudah mencapai indicator yang ditargetkan yaitu $\geq 80 \%$.

Peningkatan hasil observasi penerapan scientific approach dalam group investigation dapat dilihat pada gambar 1 :

Tabel 1. Keterlaksanaan Muatan Pelajaran Sains dengan Scientific Approach dalam Group Investigation

\begin{tabular}{clcc}
\hline & & Guru & Siswa \\
\hline Siklus I & Rata-Rata & 3,35 & 3,25 \\
& Presentase & $83,75 \%$ & $81,25 \%$ \\
& Kategori & Baik & Baik \\
\hline \multirow{2}{*}{ Siklus II } & Rata-Rata & 3,55 & 3,45 \\
& Presentase & $88,75 \%$ & $86,25 \%$ \\
& Kategori & Amat Baik & Amat Baik \\
\hline \multirow{2}{*}{ Siklus III } & Rata-Rata & 3,70 & 3,65 \\
& Presentase & $92,50 \%$ & $91,25 \%$ \\
& Kategori & Amat Baik & Amat Baik \\
\hline
\end{tabular}

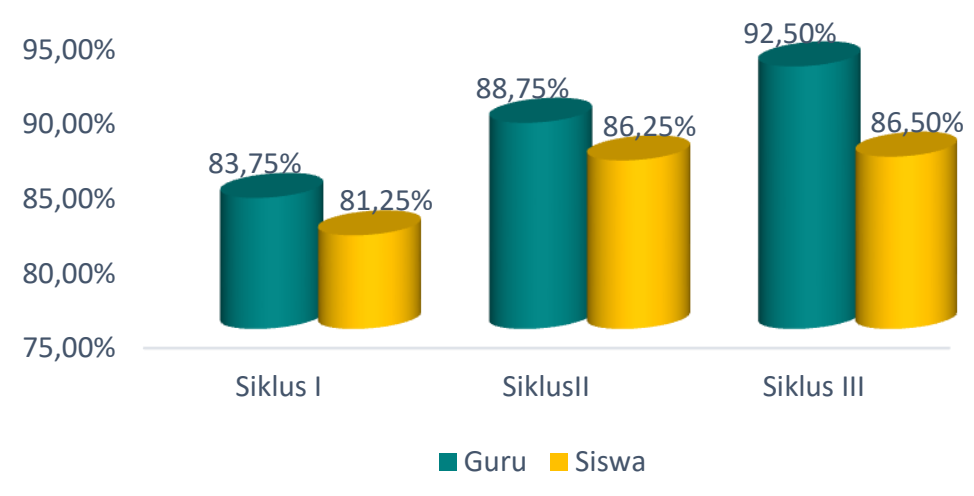

Gambar 1. Diagram Hasil Observasi Scientific Approach dalam Group Investigation 
Scientific approach dalam group investigation dalam pembelajaran IPA diterapkan dengan Langkah-langkah sebagai berikut:

(1) Goals, pada tahap ini siswa memahami tujuan investigasi yang akan dilakukan, siswa mulai memahami penjelasan dari guru terkait objek investigasi yang akan digunakan oleh siswa (mengamati), (2) Motivation, siswa antusias melakukan tanya jawab dengan teman satu kelompoknya tentang investigasi yang akan dilakukan (menanya) (3) Planning Activities, siswa bersama-sama dengan teman satu kelompok berdiskusi membuat rencana investigasi (mengamati, menanya, menalar), (4) Materials, siswa mempersiapkan alat dan bahan yang dibutuhkan dengan teliti dan benar. (5) Group Activities, siswa melakukan investigasi bersama teman-teman dalam kelompoknya, saling berbagi tugas dalam menganalisis dan mengumpulkan data investigasi (mencoba)
(6) Closure, siswa mengumpulkan hasil investigasi dan mencatatnya dalam satu lembar kerja. (7) Appraisal and Feedback, siswa mempresentasikan hasil diskusi di depan kelas untuk mendapatkan masukan dari guru dan teman-teman lainnya (mengkomunikasikan), (8) Reflection Siswa menanggapi pertanyaan, masukan dari guru dan teman-teman dikelasnya untuk menyempurnakan hasil investigasi yang dipresentasikan dan diakhiri dengan kesimpulan (menyimpulkan)

Penerapan scientific approach dalam group investigation berorientasi untuk meningkatkan keterampilan berpikir kritis siswa. Adapun hasil tes keterampilan berpikir kritis siswa setelah menerapkan scientific approach dalam group investigation mengalami peningkatan setiap siklusnya disajikan dalam table 2:

Tabel 2. Peningkatan Keterampilan Berpikir Kritis Siswa

\begin{tabular}{cccc}
\hline Siklus & Skor Rata-Rata & Presentase & Kategori \\
\hline I & 23,5 & $68,57 \%$ & Cukup \\
II & 29,5 & $85,71 \%$ & Amat Baik \\
III & 32,5 & $91,42 \%$ & Amat Baik \\
\hline
\end{tabular}

Dari hasil tes keterampilan berpikir kritis siswa, diketahui bahwa keterampilan berpikir kritis siswa mengalami peningkatan pada setiap siklusnya, Diketahui dari hasil skor rata-rata tes pada setiap pertemuan di setiap siklusnya mengalami peningkatan. Pada siklus I skor rata - rata 23,4 dengan presentase $68,57 \%$, pada siklus I ini diketahui presentase keterampilan berpikir kritis ssiwa masih rendah sehingga hanya tergolong dalam kategori Cukup. Pada siklus II mengalami peningkatan yang signifikan, yaitu mencapai 29,5 dengan presentase ketercapaian $85,71 \%$. Pada siklus III terus mengalami peningkatan menjadi 32,5 atau 91,42\% dalam kategori Amat Baik. Dari hasil tes tersebut diketahui bahwa keterampilan berpikir kritis siswa mengalami peningkatan dan telah mencapai 
target yang diinginkan yaitu $\geq 80 \%$. Lebih jelas

dapat dilihat dalam gambar 2:

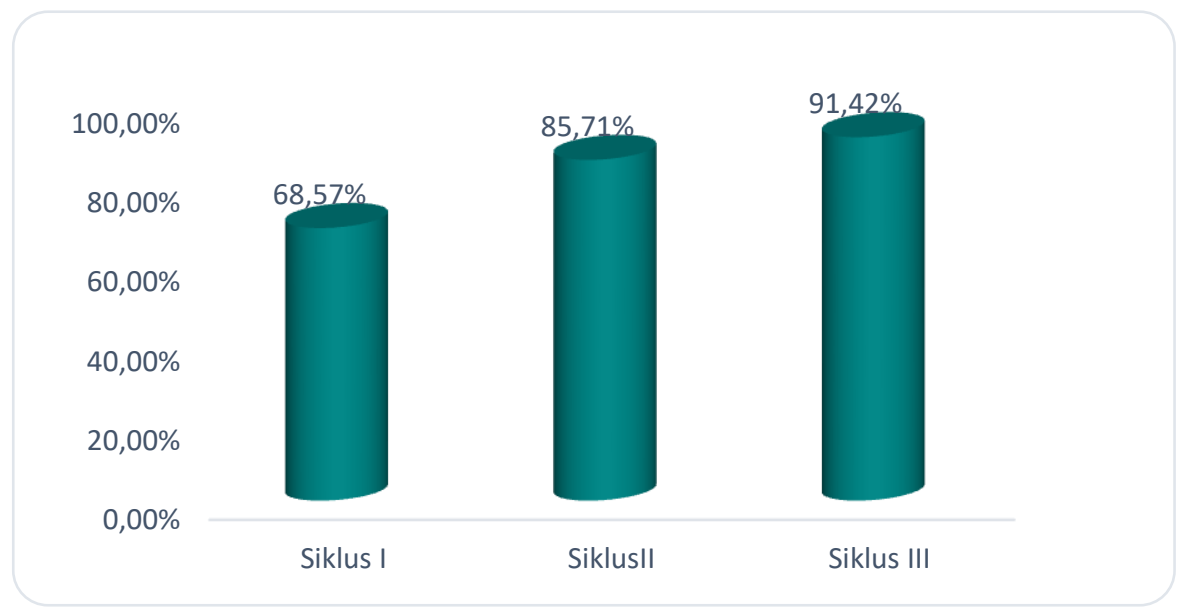

Gambar 2. Diagram Peningkatan Keterampilan Berpikir Kritis Siswa

Dimensi berpikir kritis yang dijadikan dasar dalam penelitian ini mencakup: (1) Focus: berfokus pada pertanyaan/masalah, (2) Finding Out: mencari tahu jawaban dari pertanyaan/masalah; (3) Analysis: menganalisis hasil observasi secara rasional; (4) Overview (menyeluruh): melihat sesuatu secara keseluruhan apakah terdapat koherensi dan relevansi antara permasalahan dan keputusan yang telah diambil; (5) Inference: membuat kesimpulan atas alasan yang telah dikemukakan.

\section{SIMPULAN}

Penerapan scientific approach dalam group investigation dilaksanakan dengan langkah-langkah: (1) Goals, (2) Motivation, (3) Planning Activities; (4) Materials; (5) Group Activities; (6) Closure; (7) Appraisal and Feedback; and (8) Reflection.Penerapan scientific approach dalam group investigation dapat meningkatkan keterampilan berpikir kritis ssiwa pada pembelajaran IPA, terbukti dari hasil tes diketahui terjadi peningkatan keterampilan berpikir kritis siswa kelas IV pada setiap siklusnya. Pada siklus I skor rata rata 23,4 dengan presentase $68,57 \%$ berada dalam kategori Cukup. Kemudian mengalami peningkatan pada siklus II yaitu mencapai 29,5 dengan presentase ketercapaian $85,71 \%$ dalam kategori Amat Baik. Pada siklus III terus mengalami peningkatan menjadi 32,5 atau 91,42\% dalam kategori Amat Baik. Dari hasil tes tersebut diketahui bahwa keterampilan berpikir kritis siswa mengalami peningkatan dan telah mencapai target yang diinginkan yaitu $\geq 80 \%$.

\section{DAFTAR PUSTAKA}

Bookfield SD. 2012. Teaching for Critical Thinking. San Frasisco: Jossey-Bass 
Brookhart M. 2010. How to Assess HigherOrder Thinking Skills in Your Classroom. Virginia: ASCD.

Danim S. 2010. Perkembangan Peserta Didik. Bandung: Alfabeta.

Demir M. 2010. Quadruple Thinking: Critical Thinking. International Conference on Education and Educational Psychology, 12(2).

Depdikbud. 2006. Peraturan Menteri Nomor 22 Tahun 2006. Jakarta: Depdikbud.

Depdiknas. 2003. Undang-Undang Republik Indonesia Nomor 20 Tahun 2003 tentang Sistem Pendidikan Nasional. Jakarta: Depdiknas.

Ennis RH. 2000. Critical Thinking: A Streamlined Conception. United States: University of Illinois.

Fisher A. 2008. Berpikir Kritis Sebuah Pengantar. Jakarta: PT Gelora Aksara Pratama.

Judge. 2009. Critical Thinking Skills for Education Students. Southernhay East: Learning Matters.

Howe AC \& Jones L. 1993. Engaging Children in Science. USA: Macmillan Publishing Company

Kemendikbud. 2014. Materi Pelatihan Guru Implementasi Kurikulum 2013 Tahun 2014 SD Kelass IV. Jakarta: Depdiknas.

Kemendikbud. 2016). Panduan Pelaksanaan

Pendidikan Karakter. Badan Penelitian dan Pengembangan Pusat Kurikulum dan Perbukuan: Jakarta.
Moon J. 2008. Critical Thinking: An Exploration of Theory and Practice. Kanada: Routledge.

Leicester M \& Taylor D. 2010. Critical Thinking Across The Curriculum. London: Mc Grawn

Odom SL. 2005. Research in Special

Education: Scientific Methods and

Evidence-Based Practices. Journal

Of Indiana University, 1(2): 137148.

Ozden Y. 2008. Learning and Teaching. Ankara: PegemA Publishing Sharan Y \& Sharan. 1998. Group Investigation Expands Cooperative Learning. USA: Association for Supervision and Curriculum Development.

Trianto. 2007. Model-model Pembelajaran Inovatif Berorientasi

Konstruktivistik. Jakarta: Prestasi Pustaka.

Winataputra US. 2001. Jati Diri Pendidikan Kewarganegaraan sebagai Wahana Pendidikan Demokrasi. Desertasi. Pascasarjana UPI: Bandung Trilling \& Fadel. 2009. $21^{\text {st }}$ Century Skills: Learning for Life in Our Times. San Francisco: Jossey-Bass A Wiley Imprint. 